\title{
Genetic diversity analysis of two Eucalyptus species using ISSR markers
}

\author{
Diversidade genética de duas espécies de Eucalyptus usando marcadores ISSR
}

\author{
Giovanna Carla Teixeira', Enéas Ricardo Konzen", Júlio Cézar Tannure Faria"', \\ Douglas Santos Gonçalves ${ }^{\mathrm{v}}$, Dulcinéia de Carvalho" ${ }^{v}$, Gilvano Ebling Brondaniv ${ }^{{ }^{v}}$
}

\begin{abstract}
Here, we deployed a genetic diversity analysis using ISSR markers in two Eucalyptus species, as a fundamental step toward breeding strategies. The selected species were Eucalyptus urophylla and Eucalyptus microcorys, both with economic potential in forestry. The studied individuals belong to a species and the provenance test that was installed in 1974 and until now remains exempt from silvicultural treatments. Nine universal ISSR primers were used in the analyses. Intra and interspecific variation through the polymorphism percentage, polymorphism information content (PIC) and Euclidean distances among individuals were computed. The Euclidean distance among the individuals was used to perform a principal coordinate analysis (PCoA), as well as the permutation analysis of multivariate dispersion (PermDisp), followed by the Tukey's test. A high percentage of polymorphic bands were detected, with 57.14\% for Eucalyptus microcorys and $80.95 \%$ for Eucalyptus urophylla. PIC values were higher than 0.5 for four primers (UBC827, UBC835, UBC841, and UBC842). The genetic variability was significantly higher within the Eucalyptus urophylla population than in Eucalyptus microcorys, which may be associated with the greater ability of Eucalyptus urophylla to naturally hybridize, therefore, enabling the introduction of new alleles to their populations.
\end{abstract}

Keywords: Genetic breeding; Genetic reserve; Eucalyptus urophylla; Eucalyptus microcorys

\section{Resumo}

Visando fornecer informações que sirvam de base para estudos de melhoramento genético de Eucalyptus foi realizada a análise da diversidade genética usando marcadores ISSR. As espécies estudadas foram Eucalyptus urophylla e Eucalyptus microcorys, ambas com potencial econômico florestal. Os indivíduos estudados pertencem a um teste de espécies e procedências instalado no ano de 1974 e permanecem isentos de tratos silviculturais. Para as análises foram utilizados nove primers ISSR universais. A partir dos resultados avaliou-se a existência de variação intra e interespecífica por meio da porcentagem de polimorfismo, conteúdo de informação polimórfica (PIC) e distância Euclidiana entre indivíduos. A fim de analisar a distância Euclidiana entre os indivíduos foram feitas a análise de coordenadas principais (PCoA) e análise permutacional de dispersão multivariada (PermDisp) seguida pelo teste de Tukey. Observouse elevada porcentagem de polimorfismo (57,14\% para Eucalyptus microcorys e 80,95\% para Eucalyptus urophylla). Considerando todos os grupos avaliados, os valores de PIC foram superiores a 0,5 para quatro primers (UBC827, UBC835, UBC841). A variabilidade interna foi significativamente maior na população de Eucalyptus urophylla em relação à Eucalyptus microcorys, o que pode estar associado à maior capacidade do Eucalyptus urophylla em hibridizar naturalmente.

Palavras-chave: Melhoramento genético; Reserva genética; Eucalyptus urophylla; Eucalyptus microcorys

\footnotetext{
Engenheira Florestal, M.Sc., Departamento de Ciências Florestais, Universidade Federal de Lavras, Campus Universitário, S/N, Caixa Postal 3037, CEP 37200-900, Lavras (MG), Brasil. giovannateixeira_959@hotmail.com (ORCID: 0000-0001-9894-5501)

Engenheiro Florestal, Dr., Professor do Departamento Interdisciplinar, Campus Litoral Norte, Centro de Estudos Costeiros Limnológicos e Marinhos, Universidade Federal do Rio Grande do Sul, Av. Tramandaí, n. 976, Centro, CEP 95625-000, Imbé (RS), Brasil. erkonzen@gmail.com (ORCID: 0000-0001-5176-7410)

III Engenheiro Florestal, M.Sc., Doutorando em Engenharia Florestal, Departamento de Ciências Florestais, Universidade Federal de Lavras, Campus Universitário, S/N, Caixa Postal 3037, CEP 37200-900, Lavras (MG), Brasil. jc.tannure@gmail.com (ORCID: 0000-0001-7081-3726)

IV Engenheiro Florestal, M.Sc., Doutorando em Engenharia Florestal, Departamento de Ciências Florestais, Universidade Federal de Lavras, Campus Universitário, S/N, Caixa Postal 3037, CEP 37200-900, Lavras (MG), Brasil. goncalvesds27@gmail.com (ORCID: 0000-0003-2580-8463)

Engenheira Florestal, Drª.., Professora do Departamento de Ciências Florestais, Universidade Federal de Lavras, Campus Universitário, S/N, Caixa Postal 3037, CEP 37200-900, Lavras (MG), Brasil. dulce@ufla.br (ORCID: 0000-0001-9447-4538)

vi Engenheiro Florestal, Dr., Professor do Departamento de Ciências Florestais, Universidade Federal de Lavras, Campus Universitário, S/N, Caixa Postal 3037, CEP 37200-900, Lavras (MG), Brasil. gilvano.brondani@ufla.br (ORCID: 0000-0001-8640-5719)
} 


\section{Introduction}

Breeding involves the selection of characteristics of interest in plant materials, such as technological properties, resistance to pests and diseases and their adaptation to climate fluctuation. Therefore, knowledge on the genetic diversity of germplasm collections is essential, especially in the case of obtaining genetic gains, taking into consideration the possibility of recognizing characters that may be of economic interest. Analyses of the genetic diversity and the genetic structure of populations have often been conducted with molecular techniques that directly access the DNA, thus avoiding the environmental influence and offering higher precision in the genetic diversity estimates (MONDINI; NOORANI; PAGNOTTA, 2009; KONZEN, 2014; KONZEN et al., 2017).

Molecular markers have been generally obtained through polymerase chain reaction (PCR), the in vitro enzymatic synthesis of millions of copies of a DNA fragment. After each cycle, the fragment is duplicated, creating a chain reaction, since each molecule synthesized can serve as a template for the next cycle (GROVER; SHARMA, 2016). ISSR markers are among the PCR-derived methods for genetic analyses which do not require prior information of the DNA sequence. Therefore, this method stands out as an efficient alternative for complex genome characterization. These markers consist of DNA fragments with 100 to 3,000 bp, amplified by PCR using only one primer, which usually contains 16 to $25 \mathrm{bp}$. These fragments are flanked at both ends by microsatellite sequences. Its application has the advantage of generating many informative bands per reaction and with high reproducibility (JONES et al., 2009; NG; TAN, 2015; GROVER; SHARMA, 2016).

Molecular tools have been implicated in important productive sectors such as forestry. Such methods have enabled in the selection for an increased productivity of forest stands and thus diminishing the demand for expanding planted areas (GOLLE et al., 2009; REZENDE et al., 2014). In Brazil, this sector is mainly represented by eucalypt cultivation (ARRIEL et al., 2019; OLIVEIRA; SANTANA; OLIVEIRA, 2019), having great economic, social and environmental importance due to its participation in job generations, the reduction of the exploitation of native forests and the raw material supply for several industrial segments. Therefore, having knowledge of the genetic diversity of new genetic materials of Eucalyptus is important for selecting improved materials and increasing the productivity and the wood quality even more than what it is already available.

In this study, we analyzed the genetic variation of the individuals from two Eucalyptus species (i.e., Eucalyptus urophylla S. T. Blake and Eucalyptus microcorys F. Muell) of economic interest through ISSR markers, aiming to provide information on the available germplasm for further selection and breeding. The individuals belong to a species and provenances test located in Lavras, Minas Gerais state, Brazil, which has valorous germplasm yet to be explored for breeding eucalypts.

\section{Material and methods}

The samples were collected from adult individuals (aged more than 44 years) of Eucalyptus urophylla and Eucalyptus microcorys, belonging to a species and provenance test carried out in 1974 by the Forest Research Program (PRODEPEF) and the Brazilian Agricultural Research Corporation (EMBRAPA) in the Federal University of Lavras (UFLA) campus, located in the municipality of Lavras (21 $\left.{ }^{\circ} 13^{\prime} \mathrm{S}, 44^{\circ} 58^{\prime} \mathrm{W}\right)$, Minas Gerais state. The Eucalyptus microcorys genetic material used in the test was collected in the Coffs Harbor region, northern coast of Australia $\left(28^{\circ} 30^{\prime} \mathrm{S}\right.$ and $\left.153^{\circ} 19^{\prime} \mathrm{W}\right)$, at an altitude of $182 \mathrm{~m}$. The individuals of Eucalyptus urophylla are originally from the Queorema region, Timor, between $08^{\circ} 53^{\prime} \mathrm{S}$ and $125^{\circ} 32^{\prime} \mathrm{W}$ and, $2,040 \mathrm{~m}$ of altitude. In this test, each species constituted a plot with 25 individuals and $3 \times 2 \mathrm{~m}$ of spacing (MOURA et al., 1980). It is important to emphasize that the genetic materials are free of any 
genetic modification purpose and present satisfactory results regarding the adaptation in the region, which makes them especially interesting for studies on genetic breeding.

DNA extractions were performed using adaptations to the protocol proposed by Doyle and Doyle (1990), using fresh adult leaves of eight individuals of Eucalyptus microcorys and six individuals of Eucalyptus urophylla, according to material availability in the study area. The DNA samples were quantified and evaluated qualitatively using the NanoVuePlus ${ }^{\mathrm{TM}}$ spectrophotometer following the manufacturer's specifications. For the amplifications, nine universal ISSR primers were used (Table 1) and the reactions were prepared in microplates containing $3 \mu \mathrm{L}$ DNA (standardized at $20 \mathrm{ng} \mu \mathrm{L}^{-1}$ for all samples) and $10 \mu \mathrm{L}$ of reaction mix in each well $[1.5 \mathrm{mM}$ PCR buffer $\left(50 \mathrm{mM}\right.$ Tris-HCl pH 8.4; $0.25 \mathrm{mg} \mathrm{mL}^{-1} \mathrm{BSA} ; 20 \mathrm{mMKCl}$; $0.1 \%$ ficoll; $20 \mathrm{mM}$ of tartrazine; $\left.0.1 \mathrm{mM} \mathrm{MgCl}_{2}\right), 1.5 \mathrm{mM}$ of each dNTPs, $1 \mathrm{U}$ of Taq polymerase Phoneutria $\left(5 \mathrm{U} \mathrm{LL}^{-1}\right)$, Taq diluent solution (with BSA and Tris $\mathrm{HCl}$ ) and $0.2 \mathrm{mM}$ of each primer, and $3.25 \mu \mathrm{L}$ of ultrapure water. The PCR cycle was performed as follows: initial denaturation at $94^{\circ} \mathrm{C}$ for 2 minutes, 37 cycles of $94^{\circ} \mathrm{C}$ for 30 seconds, $42^{\circ} \mathrm{C}$ for 30 seconds and $72^{\circ} \mathrm{C}$ for 1 minute; and final extension at $72^{\circ} \mathrm{C}$ for 7 minutes. The amplified products were separated on $1.5 \%$ agarose gel and stained with Gel Red ${ }^{\mathrm{TM}}$. The interpretation of the gels was performed considering only well-defined bands, which were subsequently submitted to the marker (number of bands) sufficiency analysis, performed in GENES software (CRUZ, 2013).

Table 1 - ISSR primers used for DNA amplification

Tabela 1 - Primers ISSR utilizados para amplificação do DNA

\begin{tabular}{lc}
\hline \multicolumn{1}{c}{ Primer } & Sequence \\
\hline John & (AG)7-YC \\
Becky & $(\mathrm{CA}) 7-\mathrm{YC}$ \\
UBC807 & $(\mathrm{AG}) 8-\mathrm{T}$ \\
UBC809 & $(\mathrm{AG}) 8-\mathrm{G}$ \\
UBC827 & $(\mathrm{AC}) 8-\mathrm{G}$ \\
UBC835 & $(\mathrm{AG}) 8-\mathrm{YC}$ \\
UBC840 & $(\mathrm{GA}) 8-\mathrm{YT}$ \\
UBC841 & $(\mathrm{GA}) 8-\mathrm{YC}$ \\
UBC842 & $(\mathrm{GA}) 8-\mathrm{YG}$ \\
\hline
\end{tabular}

Source: Authors (2020)

Where: $\mathrm{R}=$ purine $(\mathrm{A}$ or $\mathrm{G})$ and $\mathrm{Y}=$ pyrimidine $(\mathrm{C}$ or $\mathrm{T})$.

After confirming marker sufficiency, the polymorphism at each band was evaluated. A binary data matrix where 0 indicates absence and 1 presence of the band was generated, from which we calculated the frequency of each band and their polymorphic information content (PIC). The PIC was calculated according to Weiler et al. (2010):

$$
P I C=1-\sum p_{i}^{2}
$$

Where: $p_{i=}$ frequency of the $i^{\text {th }}$ band of each primer.

The polymorphism was also estimated as the number of polymorphic loci $(P \%)$ for each species. Furthermore, we also determined the following statistics: observed number of alleles $(\mathrm{Na})$, effective number of alleles $\left[\mathrm{Ne}=1 /\left(p^{2}+q^{2}\right)\right]$, expected heterozygosity under Hardy-Weinberg equilibrium 
expectations $(H e=2 p q)$ and Shanon's information index $\{-1 \times[p \times \operatorname{Ln}(p)+q \times \ln (q)]\}$, where $p$ is the frequency of the band that is present on each marker and $q$ represents the absent band (alternative allele). The analyses were conducted using GenAlEx (PEAKALL; SMOUSE, 2012).

Moreover, we performed Euclidean genetic distances calculations among the individuals and species, which were used to perform a principal coordinate analysis (PCoA) (GOWER, 1966; PALMER, 2000), in order to evaluate the existence of intra and interspecific variation. Finally, based on the genetic distances among individuals of the same species, a multivariate dispersion analysis (PermDisp) was performed using centroid as a reference point (ANDERSON, 2005), followed by Tukey's tests $(P<0.05)$ to evaluate whether the two species differ in terms of within genetic variation. For the analyses, the statistical software R v3.3.1 (R DEVELOPMENT CORE TEAM, 2016) and the vegan (OKSANEN et al., 2013) and betapart (BASELGA; ORME, 2012) packages were used.

\section{Results and discussion}

From the analyses of the gels (Figure 1), the individual M5 of Eucalyptus microcorys was eliminated from the data, as low resolution of its bands and their reproducibility over distinct replicates were obtained. Thus, seven individuals of Eucalyptus microcorys and six of Eucalyptus urophylla were considered for the statistical analyses.

In total, 42 bands were considered, an average of five bands per primer. The frequency of each band and the PIC value of the group of individuals and each species are shown in Table 2. Botstein et al. (1980) and Smith et al. (1997) have suggested that primers with PIC values greater than 0.5 indicate high information content, while values lower than 0.25 indicate low content, meaning little ability to discriminate individuals. According to this criterion, the primers UBC827, UBC835, UBC841 and UBC842 are recommended for Eucalyptus microcorys. For Eucalyptus urophylla almost all primers used, except for UBC840, are recommended. For both species, the primer UBC840 presented only one easily discernible band, which was monomorphic.

The percentage of polymorphism found was $57.14 \%$ for Eucalyptus microcorys and $80.95 \%$ for Eucalyptus urophylla (Table 3), indicating high potential of polymorphism detection and, therefore, a good performance of ISSR-screening method in the analysis of the genetic diversity of these materials. Under a biological point of view, this result indicated lower polymorphism in the population of $E$. microcorys. The same can be observed from the PIC values of most primers. PIC values were lower in E. microcorys than in E. urophylla, revealing lower genetic diversity in the former population.

\section{Figure 1 - Electrophoretic profile of John, Becky and UBC807 primers}

Figura 1 - Perfil eletroforético dos primers John, Becky e UBC807

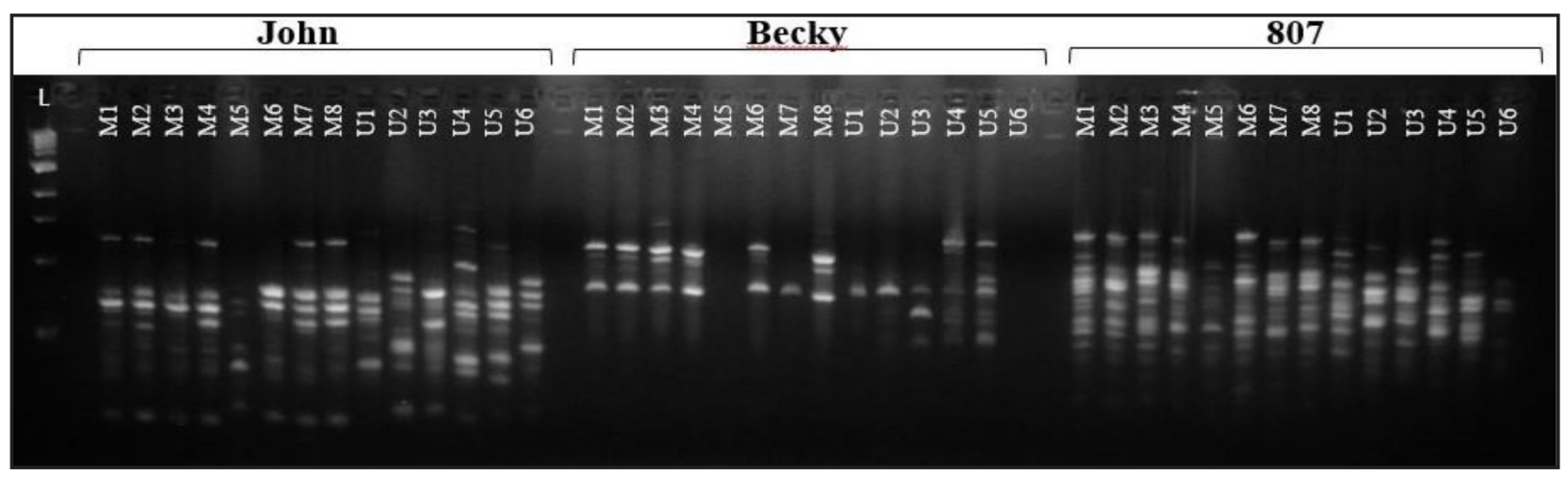

Source: Authors (2020)

Where: $\mathrm{L}=1 \mathrm{~kb}$ plus DNA Ladder marker; M1 to M8 = individuals of Eucalyptus microcorys; U1 to U6 = individuals of Eucalyptus urophylla. 
The other genetic diversity statistics of the two populations also showed that E. microcorys has lower genetic diversity than E. urophylla. Specifically, the expected heterozigosity under HW equilibrium was of 0.279 in E. urophylla and of 0.217 in E. microcorys (Table 3).

From the principal coordinate analysis and PermDisp, significantly higher within-species genetic variation was detected in Eucalyptus urophylla than in Eucalyptus microcorys (Figure 2). This is probably due to their distinct ability to hybridize. Whereas Eucalyptus urophylla is attributed high capacity of hybridization with other species of the genus, for Eucalyptus microcorys there are no reports of the occurrence of this event (PRYOR, 1971). Thus, it is likely that throughout the evolutionary process the species Eucalyptus urophylla has undergone successive hybridizations that contributed to its high genetic diversity, while the same would not have occurred for Eucalyptus microcorys. The prominent distinction between the two species are responsible even for their classification into different subgenus, with Eucalyptus urophylla inside the wide Symphyomyrtus subgenus and Eucalyptus microcorys as the single member of the Alveolata subgenus (BROOKER, 2000; STEANE et al., 2011).

The high genetic diversity in Eucalyptus urophylla as an outcome of hybridization is recognized in studies that link the occurrence of this event in natural and controlled conditions. An example of a natural hybridization involving the species is presented in Martin and Cossalter (1976), in which hybrids between Eucalyptus urophylla and Eucalyptus alba are reported under natural conditions in the islands of the Indonesian archipelago. Hybridization under controlled conditions is widely used in the Brazilian forest sector, with the species composing hybrids with other species, such as the expressively used "urograndis". This hybrid is obtained by the cross between Eucalyptus urophylla and Eucalyptus grandis and accounts for $80 \%$ of Brazilian eucalypt plantations, being the main material used (FONSECA et al., 2010; PALUDZYSZYN FILHO; SANTOS, 2011; OLIVEIRA; SANTANA; OLIVEIRA, 2019). In contrast, the low genetic diversity associated with the restriction of hybridization found in Eucalyptus microcorys justifies the lack of genetic studies with the species, as well as its incipient use in breeding programs.

Dvorak, Hodge and Payn (2008), studying Eucalyptus urophylla, emphasized on the current scenario of climate change and the development of new diseases, the adaptability of species will probably change over time. In this scenario, they highlight the importance of conservation areas composed of materials from native regions, such as the study area, that can serve as a genetic basis for composing seed orchards, as they are an important source of genetic variation in breeding programs.

Table 2 - Frequency for each band and polymorphism information content (PIC), evaluated at group and for each species

Tabela 2 - Resultados de frequência para cada banda e conteúdo de informação polimórfica (PIC) avaliados para o conjunto e para cada espécie

\begin{tabular}{cccccccccc}
\hline \multirow{2}{*}{ Primer } & \multirow{2}{*}{ Type of analysis } & \multicolumn{7}{c}{ Frequency of each band } \\
\cline { 3 - 8 } & & $\mathbf{1}$ & $\mathbf{2}$ & $\mathbf{3}$ & $\mathbf{4}$ & $\mathbf{5}$ & $\mathbf{6}$ & $\mathbf{7}$ & PIC \\
\hline \multirow{3}{*}{ John } & Group & 0.38 & 0.08 & 0.15 & 0.85 & 0.77 & 0.31 & 0.15 & 0.77 \\
& Eucalyptus microcorys & 0.71 & & & 0.71 & 1.00 & 0.43 & 0.45 \\
& Eucalyptus urophylla & & 0.17 & 0.33 & 1.00 & 0.50 & 0.17 & 0.33 & 0.75 \\
& Group & 0.15 & 0.46 & 0.23 & 0.85 & & & & 0.75 \\
\multirow{3}{*}{ Becky } & Eucalyptus microcorys & & 0.86 & 0.43 & 1.00 & & & & 0.36 \\
& Eucalyptus urophylla & 0.33 & & & 0.67 & & & & 0.72
\end{tabular}


Tabela 2 - Conclusão ...

Table 2 - Conclusion ...

\begin{tabular}{|c|c|c|c|c|c|c|c|c|c|}
\hline \multirow{2}{*}{ Primer } & \multirow{2}{*}{ Type of analysis } & \multicolumn{7}{|c|}{ Frequency of each band } & \multirow{2}{*}{ PIC } \\
\hline & & 1 & 2 & 3 & 4 & $\mathbf{5}$ & 6 & 7 & \\
\hline \multirow{3}{*}{ UBC807 } & Group & 0.62 & 0.23 & 0.23 & 0.62 & 0.69 & & & 0.73 \\
\hline & Eucalyptus microcorys & 1.00 & & 0.14 & 1.00 & 0.71 & & & 0.37 \\
\hline & Eucalyptus urophylla & 0.17 & 0.50 & 0.33 & 0.17 & 0.67 & & & 0.83 \\
\hline \multirow{3}{*}{ UBC809 } & Group & 0.23 & 0.77 & 1.00 & 0.85 & 0.77 & 0.46 & 0.23 & 0.54 \\
\hline & Eucalyptus microcorys & 0.29 & 1.00 & 1.00 & 0.86 & 0.86 & 0.14 & & 0.40 \\
\hline & Eucalyptus urophylla & 0.17 & 0.50 & 1.00 & 0.83 & 0.67 & 0.83 & 0.50 & 0.52 \\
\hline \multirow{3}{*}{ UBC827 } & Group & 0.15 & 0.08 & 0.54 & 0.46 & & & & 0.87 \\
\hline & Eucalyptus microcorys & 0.29 & 0.14 & 0.43 & 0.57 & & & & 0.85 \\
\hline & Eucalyptus urophylla & & & 0.67 & 0.33 & & & & 0.72 \\
\hline \multirow{3}{*}{ UBC835 } & Group & 0.54 & 0.31 & 0.69 & 0.23 & 0.23 & & & 0.81 \\
\hline & Eucalyptus microcorys & 0.86 & 0.43 & 0.57 & & & & & 0.59 \\
\hline & Eucalyptus urophylla & 0.17 & 0.17 & 0.83 & 0.50 & 0.50 & & & 0.75 \\
\hline \multirow{3}{*}{ UBC840 } & Group & 1.00 & & & & & & & 0.00 \\
\hline & Eucalyptus microcorys & 1.00 & & & & & & & 0.00 \\
\hline & Eucalyptus urophylla & 1.00 & & & & & & & 0.00 \\
\hline \multirow{3}{*}{ UBC841 } & Group & 0.38 & 0.46 & 0.62 & 0.69 & 0.54 & & & 0.70 \\
\hline & Eucalyptus microcorys & & 0.57 & 0.57 & 0.57 & 0.86 & & & 0.57 \\
\hline & Eucalyptus urophylla & 0.83 & 0.33 & 0.67 & 0.83 & 0.17 & & & 0.61 \\
\hline \multirow{3}{*}{ UBC842 } & Group & 0.54 & 0.23 & 0.23 & 0.62 & & & & 0.81 \\
\hline & Eucalyptus microcorys & 0.57 & 0.14 & & 1.00 & & & & 0.55 \\
\hline & Eucalyptus urophylla & 0.50 & 0.33 & 0.50 & 0.17 & & & & 0.84 \\
\hline
\end{tabular}

Source: Authors (2020)

Where: PIC = Polymorphism information content.

Table 3 - Population genetic statistics for ISSR markers in a population of Eucalyptus microcorys and a population of Eucalyptus urophylla

Tabela 3 - Estatísticas genético-populacionais de marcadores ISSR em uma população de $E$. microcorys e uma população de Eucalyptus urophylla

\begin{tabular}{lcccc}
\hline \multicolumn{1}{c}{ Species } & Na & Ne & I & He \\
\hline E. microcorys & $1.333( \pm 0.131)$ & $1.382( \pm 0.062)$ & $0.319( \pm 0.047)$ & $0.217( \pm 0.033)$ \\
E. urophylla & $1.690( \pm 0.105)$ & $1.471( \pm 0.055)$ & $0.420( \pm 0.038)$ & $0.279( \pm 0.028)$ \\
\hline
\end{tabular}

Source: Authors (2020)

Where: Each value is followed by their measure of standard error. 
Figure 2 - Principal coordinate analysis (PCoA) (A) and multivariate dispersion analysis (PermDisp) $(B)$ results based on the Euclidean distance matrix between individuals

Figura 2 - Resultados da análise de coordenadas principais (PCoA) (A) e análise de dispersão multivariada (PermDisp) (B) baseadas na matriz de distância Euclidiana entre os indivíduos

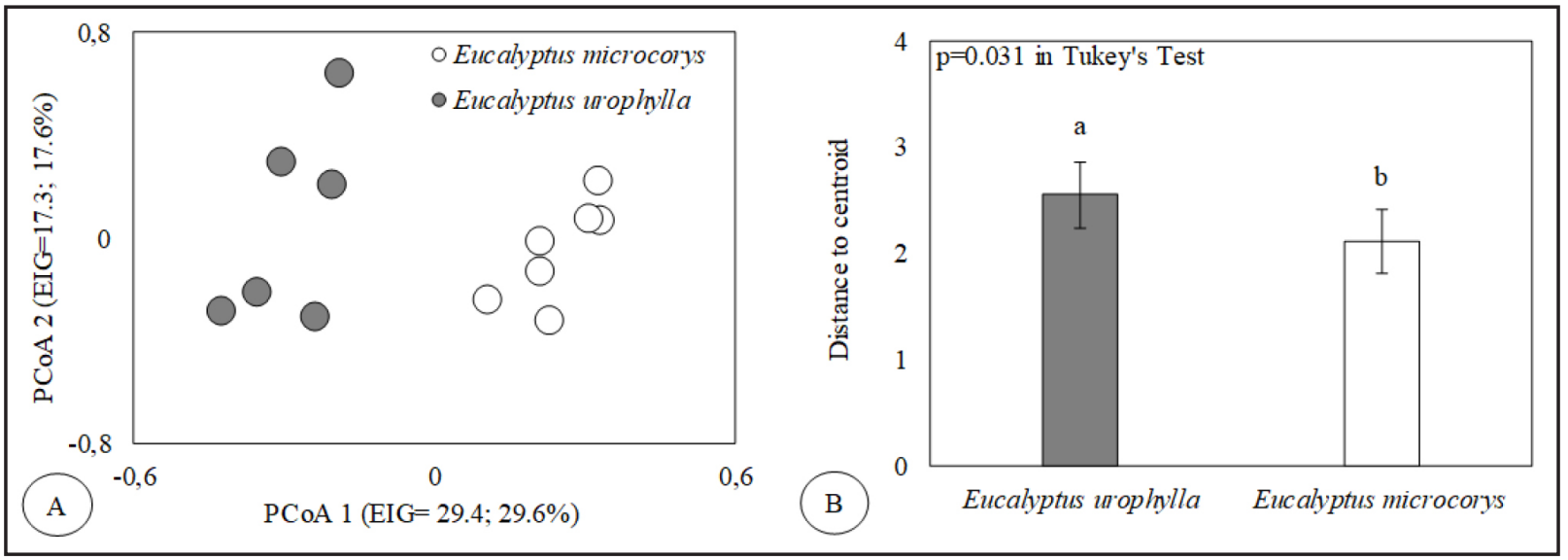

Source: Authors (2020)

Our results showed the usefulness of ISSR markers for the discrimination of the genetic materials, as also was used to evaluate the genetic diversity of Pinus sylvestris L. (CIPRIANO et al., 2016), Pinus pinaster Ait., (LUCAS-BORJA et al., 2016), Schizolobium parahyba var. amazonicum (Huber ex Ducke) Barneby (SILVA JÚNIOR et al., 2017) and Tectona grandis L. f. (CHIMELLO et al., 2017). Thus, the information from its application open precepts for future studies that can promote advances in the industry, such as the development of new, more adapted and productive materials.

\section{Conclusions}

Higher genetic diversity was detected within the population of E. urophylla than the population of E. microcorys. This could be related to the natural crossing potential of each species.

For Eucalyptus urophylla, eight of the nine primers tested were recommended, whereas for Eucalyptus microcorys just four primers (UBC827, UBC835, UBC841 and UBC842) showed significant number of bands easily discernible.

\section{Acknowledgements}

We thank the National Council for Scientific and Technological Development, Brazil (Conselho Nacional de Desenvolvimento Científico e Tecnológico - CNPq), Coordination for Improvement of Higher Education Personnel, Brazil (Coordenação de Aperfeiçoamento de Pessoal de Nível Superior - CAPES), and Foundation for Research of the State of Minas Gerais, Brazil (Fundação de Amparo a Pesquisa do Estado de Minas Gerais - FAPEMIG) for their financial support and scholarships for the students. 


\section{References}

ANDERSON, M. J. Distance based tests for homogeneity of multivariate dispersions. Biometrics, Washington, v. 62, n. 1, p. 245-253, 2005.

ARRIEL, T. G. et al. Developing near infrared spectroscopic models for predicting density of Eucalyptus wood based on indirect measurement. Cerne, Lavras, v. 25, n. 3, p. 294-300, 2019.

BASELGA, A.; ORME, C. D. L. Betapart: an R package for the study of beta diversity. Methods in Ecology and Evolution, London, v. 3, n. 5, p. 808-812, 2012.

BOTSTEIN, D. et al. Construction of a genetic linkage map in man using restriction fragment length polymorphisms. American Journal of Human Genetics, Chicago, v. 32, n. 3, p. 314-331, 1980.

BROOKER, M. I. H. A new classification of the genus Eucalyptus L'Her. (Myrtaceae). Australian Systematic Botany, Clayton, v. 13, n. 1, p. 79-148, 2000.

CHIMELLO, A. M. et al. Morphological descriptors and ISSR molecular markers in the evaluation of genetic variability of Tectona grandis genotypes. Genetics and Molecular Research: GMR, Ribeirão Preto, v. 16, n. 2, p. 1-16, 2017.

CIPRIANO, J. et al. Evaluation of genetic diversity of Portuguese Pinus sylvestris L. populations based on molecular data and inferences about the future use of this germplasm. Journal of Genetics, London, v. 93, n. 2, p. 41-48, 2016.

CRUZ, C. D. Genes: a software package for analysis in experimental statistics and quantitative genetics. Acta Scientiarum. Agronomy, Maringá, v. 35, n. 3, p. 271-276, 2013.

DOYLE, J. J.; DOYLE, J. L. Isolation of plant DNA from fresh tissue. Focus, Rockville, v. 12, n. 1, p. 13-15, 1990.

DVORAK, W. S.; HODGE, G. R.; PAYN, K. G. The conservation and breeding of Eucalyptus urophylla: a case study to better protect important populations and improve productivity. Southern Forests: A Journal of Forest Science, Scottsville, v. 70, n. 2, p. 77-85, 2008.

FONSECA, S. M. et al. Manual prático de melhoramento genético do eucalipto. Viçosa, MG: Editora UFV, 2010. 200 p.

GOLLE, D. P. et al. Melhoramento florestal: ênfase na aplicação da biotecnologia. Ciência Rural, Santa Maria, v. 39, n. 5, p. 1606-1613, 2009.

GOWER J. C. Some distance properties of latent root and vector methods used in multivariate analysis. Biometrika, Oxford, v. 53, n. 3-4, p. 325-338, 1966.

GROVER, A.; SHARMA, P. C. Development and use of molecular markers: past and present. Critical Reviews in Biotechnology, London, v. 36, n. 2, p. 290-302, 2016.

JONES, N. et al. Markers and mapping revisited: finding your gene. New Phytologist, Oxford, v. 183, n. 4, p. 935-966, 2009.

KONZEN, E. R. Towards conservation strategies for forest tree endangered species: the meaning of population genetic statistics. Advances in Forestry Science, Cuiabá, v. 1, n. 1, p. 45-51, 2014.

KONZEN, E. R. et al. Molecular identification of bamboo genera and species based on RAPDRFLP markers. Silva Fennica, Helsinki, v. 51, n. 4, p. 1-16, 2017.

LUCAS-BORJA, M. E. et al. Evaluation of fire recurrence effect on genetic diversity in maritime pine (Pinus pinaster Ait.) stands using Inter-Simple Sequence Repeat profiles. Science of the Total Environment, Amsterdam, v. 572, n. 1, p. 1322-1328, 2016. 
MARTIN, B.; COSSALTER, C. Les Eucalyptus des lles de la Sonde. Bois et Forêts des Tropiques, Montpellier, v. 4, n. 166, p. 3-22, 1976.

MONDINI, L.; NOORANI, A.; PAGNOTTA, M. A. Assessing plant genetic diversity by molecular tools. Diversity, Basel, v. 1, n. 1, p. 19-35, 2009.

MOURA, V. P. G. et al. Avaliação de espécies e procedências de Eucalyptus em Minas Gerais e Espírito Santo: resultados parciais. Brasília: EMBRAPA; CPAC, 1980. 104 p.

NG, W.; TAN, S. Inter-Simple Sequence Repeat (ISSR) markers: are we doing it right? ASM Science Journal, Kuala Lumpur, v. 9, n. 1, p. 30-39, 2015.

OLIVEIRA, L. F. R.; SANTANA, R. C.; OLIVEIRA, M. L. R. Nondestructive estimation of leaf nutrient concentrations in Eucalyptus plantations. Cerne, Lavras, v. 25, n. 2, p. 184-194, 2019.

OKSANEN, J. et al. Package 'vegan'. [S. l.]: Community Ecology Package, 2013. v. 2. 295 p.

PALMER, M. Ordination methods for ecologists. Oklahoma: Oklahoma State University, Botany Department, 2000. Available in: http://ordination.okstate.edu/. Accessed in: 26 may 2018.

PALUDZYSZYN FILHO, E.; SANTOS, P. E. T. Programa de melhoramento genético de eucalipto da Embrapa Florestas: resultados e perspectivas. Colombo: Embrapa Florestas, 2011. $66 \mathrm{p}$.

PEAKALL, R.; SMOUSE, P. E. GenAlEx 6.5: genetic analysis in Excel. Population genetic software for teaching and research - an update. Bioinformatics, v. 28, n 19, p. 2537-2539, 2012.

PRYOR, L. D. Aspectos da cultura do eucalipto no Brasil. IPEF, Piracicaba, n. 2/3, p. 53-59, 1971.

R DEVELOPMENT CORE TEAM. R: a language and environment for statistical computing. Vienna: R Foundation for Statistical Computing, 2016.

REZENDE, G. D. S. P. et al. Eucalyptus breeding for clonal forestry. In: FENNING, T. (ed.) Challenges and opportunities for the world's forests in the 21 st century. Dordrecht: Springer, Forestry Sciences, 2014. v. 81. p. 393-424.

SILVA JÚNIOR, A. L. et al. Genetic diversity of Schizolobium parahyba var. amazonicum (Huber ex Ducke) Barneby, in a forest area in Brazil. Genetics and Molecular Research: GMR, Ribeirão Preto, v. 16, n. 3, p. 1-10, 2017.

SMITH, J. S. C. et al. An evaluation of the utility of SSR loci as molecular markers in maize (Zea mays L.): comparisons with data from RFLPs and pedigree. Theoretical and Applied Genetics, Berlin, v. 95, n. 1/2, p. 163-173, 1997.

STEANE, D. A. et al. Population genetic analysis and phylogeny reconstruction in Eucalyptus (Myrtaceae) using high-throughput, genome-wide genotyping. Molecular Phylogenetics and Evolution, San Diego, v. 59, n. 1, p. 206-224, 2011.

WEILER, R. L. et al. Caracterização molecular de uma progênie de tangerineira 'Clementina Fina' e 'Montenegrina'. Ciência Rural, Santa Maria, v. 40, n. 7, p. 1523-1529, 2010. 